\title{
ORAL LITERATURE OF THE SUKUMA
}

\section{Immaculate Mirambo}

This short overview of Basukuma oral literature is based on the author's field work materials. The material was collected in the late 1990s and a study on the same topic was written that the present paper is based on. The first part of the article provides a short historical background of the Basukuma of Mwanza of Tanzania, the second part introduces via sample texts the Basukuma fictional stories. The conclusion sum up the improtance of oral stories for the society.

\section{THE HISTORICAL BACKGROUND OF THE BASUKUMA OF MWANZA, TANZANIA}

The Basukuma originated from the Balongo tribe who lived on the Western side of lake Victoria. The area is now known as Geita District. There is no evidence of the original inhabitants of the Sukuma area, however according to the Hamitic Families the country was very bushy - Dense in some parts with woodland and sparse in some others.

The country was sparsely populated, mainly scattered settlements of a few hundred or so people under the leadership of a "Ntemi". The "Ntemi" evolved into chiefs once the migrant groups (clans) settled.

The Basukuma are a bantu speaking people, covering four administrative districts, that is Mwanza, Kwimba, Maswa and Shinyanga, plus the country west of Smith Sound.

There are a number of narratives that try to explain the origin and settlement of the Basukuma in Northern Tanzania. Almost every settlement (clan) has its own narrative. The most common and widely accepted in the Mwanza region is about Nkanda.

Nkanda is believed to have been the leader (Ntemi) of about 250 people. Men and women who settled at a site about 12 miles from 
Mwanza on Nyerere road. This group (clan) came from Lushamba, an area in the present day Geita District.

Exhausted by the long journey, Nkanda expressed his wish to camp Nye-Nsukumale aha 'Let me camp here'.

From that time this famous camp (settlement) was called Sukumale aha. Later on when Sanga was officially enthroned as chief in 1504, the place was referred to as Sukuma. The various settlements (clans) had little communication with each other, the concept of ethnic unity never occurred to them.

The Sukuma practised mixed farming, and were also hunters. Boys took the cattle to graze in the plains/communal grazing land. During the dry season they grazed in the woodlands.

The subsistence crops of the Basukuma are mainly maize, millet, rice sweet potatoes and vegetables. Livestock was slaughtered only during ceremonies, rituals, and large family gatherings. Nowadays the occasional cow and goat are sold for money to cater for educational and family needs.

The Basukuma are a patrilineal/society. The role of the women being to take care of their husbands and children. Young people marry only when they are ready to carry the responsibilities marriage entails. They are initiated into adulthood in a ceremony known as lhane. The Basukuma do not practice circumcision as part of initiation, but organize a separate ceremony. The young people involved in "lhane" have to be prepared well. Respected elders of the community tutor the initiates on their roles and responsibilities in the family and the whole community. The initiates have to think, act and participate as adults in all rituals. After 'lhane' the initiates are considered adults and cannot be asked to deliver messages anywhere as this is a job for non-initiates.

The role of oral poetry cannot be underestimated as it is through song and dance that some of the societies ideals are inculcated into the initiates. A song like 'Ubumanga Butashilaga' is sung in this ceremony. The Basukuma are among the most cheerful people in Tanzania. Song and dance come naturally to the Basukuma in rituals, ceremonies, childbirth, death, work, etc. Usually they do not 
speak directly what is in their minds. They do not show anger and irritation easily except when they are annoyed. If they do not agree with someone else's suggestion they will just say 'yes' and ignore or go their own way. Once they loose confidence with someone or something they do not restore it easily.

In Mwanza District, especially in the urban centres, one finds people from almost all ethnic groups of Tanzania. The major ethnic groups being the Kerewe, Kara, Jita, Haya and Chaga. These are mainly business people or employees of companies and organizations, plus those who have opted to settle in the region. The Basukuma are the majority in the Mwanza region, 95\% of them in rural areas and villages. The Basukuma are lso the largest of Tanzania's 120 ethnic groups, representing about $20 \%$ of the Tanzanian population.

\section{ORAL NARRATIVES}

A narrative is basically a prose account of people events, places that may be factual or fictional. The accounts are principally handed down from person to person and generation to generation through word of mouth. The terms 'tales' and 'folktale' have been used to denote, the same concept. Among the Sukuma, oral narratives fall into two main categories, real and imaginary narratives. Real narratives tell us something that actually happened eg. the narratives dealing with different diseases, drought that culminated in famine, floods, war and its miseries. These narratives are real for they actually happened. The second category is the imaginative narrative (fiction). These are creative, and deal with imaginary things.

Real and fictional narratives can be historical e.g. about a war, famine, disease, geographical object, etc. Real and fictional narratives communicate messages to man, man's environment and behaviour.

Folktales which are a people's popular narratives handed down orally from past generations. They express the mind of the people. Themes in folktales are mainly on cultural issues and man's behaviour. Most of the folktales are animal stories. 
The Basukuma are famous for their narratives. Their stories are used to instruct, teach, warn and set qualitative standards in order to encourage good performance. They are usually very entertaining. The variety of Basukuma narratives includes myths, ogre stories, spirits (shingwengwe), animal races (especially about the hare's cunning). Other stories of the Basukuma deal directly with life of different people: fraudulent people as well as stupid people, truly loving people, etc.

The Basukuma are very superstitious, and most will seek aid from the Bafumu, Balaguzi and Basomboji that is medicine men, diviners and sooth sayers. The Basukuma have many stories based on their beliefs on death and sufferings. They believe that fate is determined by shing'wengwe and shishieg'we, that is ogres and spirits.

The ogres are usually shown as being half human, half demon, or as terrible monsters. Also legends spread from generation to generation. They talk of fame or superior qualities that certain individuals are endowed with.

Trickster stories based on animals like hare, spider, chameleon and squirrel are common in Sukumaland. Sukuma myths reflect religion, superstition and traditional beliefs. The myths retell early history, the creation of the world, etc.

The first ogre story tells us that some problems take a long time, even years to be solved. It also shows the Sukuma belief that death is not the ultimate end to a human being.

Long time ago, people met a huge Ogre [lishingwengwe or lyoba]. Whenever the villagers met this huge ogre they would yell in terror [Ngwana].

This cry would cause the villagers to assemble with their bows and arrows ready to confront it.

One day the ogre appeared and started swallowing all the people. Fortunately one expectant mother escaped. Later on she delivered a baby boy. As the boy grew, the mother narrated to him the ogre story, how the village was devoured, including his father. The boy decided to search for the ogre, first he killed a bird named 
jiji, he ran to his mother with pride saying "Mayu, mayu namlagha shingwengwe" ["Mother, mother I have caught and killed the ogre"], his mother laughed at him and said "Kenaka" [that is not the ogre]. "The ogre is big, you are still young you cannot kill the ogre."

Another day the young boy shot something with his bow and arrow, and told his mother he had killed the ogre. But his mother told him that was not the ogre, she advised him to wait until he was grown up.

A time came when he was mature enough to face the monster. His mother blessed and allowed him to go and kill the ogre. He went into a big forest where the ogre resided. There he met it, after a long battle, he finally overpowered the ogre.

As the young man was about to kill the ogre, it told him to cut open its stomach and all the people it had swallowed would come out.

The young man then cut open the stomach with a sharp knife and sure enough all the people were released. They thanked him and named him Masala Kulangwa [Trained in Felliance].

\section{A man bird and Ogres}

One day a man called Magulu Abili [Two Legs] went into a dense forest to cut timber for building his house. While in the forest he met a sickly bird which he helped, with food and water. The bird told Magulu Abili that one day it, too, would help him. Sceptical, Magulu Abili took home his timber.

One day as Magulu Abili was in the forest, on his way to cut more timber, he met some Ogres. On seeing him, the ogres started chasing him with intent of making a meal out of him. Magulu Abili decided to climb a tree, to escape the monsters. The bird he had helped appeared and started singing very sweetly, while moving from tree to tree. The singing distracted the ogres from their prey and, they followed the sweet sound.

Magulu Abili noticed that the ogre's were following the singing bird, and it was moving away from where he was. He slipped down the tree and returned home, thankful to the bird, that had 
saved him. He remembered the sickly irk he has helped and knew at once that it was the one that had saved him.

Magulu Abili teaches us to be kind to people who are in need and one day they will also help us no matter how lowly they are placed in society as tables could turn and they become well placed.

\section{Woman and the Ogre}

One day a young married lady wanted to visit her parents, she informed her husband, but he objected. After the birth of their first child, she asked permission, her husband objected without giving any reason.

After the birth of their second child she again raised the question of visiting her parents, this time her husband did not object but told her to wait, while he went out to hunt, so that she could take them a present of game. She waited and waited and saw no signs of her husband preparing to go out hunting, so she decided to go in defiance and anger.

She took her two children and off they went, unfortunately the shortest route home passed through a forest in which lived an ogre. And that is he route she took. Once in the forest the ogre saw them, trapped them and swallowed them. When news reached the village that she still had not arrived home, the villagers suspected she had taken the short route home. They banded together and went out to hunt the ogre. They caught it killed it and ripped open its stomach, out came the young lady with her two chiIdren. The villagers, called a council of elders meeting in which the la$d y$ 's husband was called for not being a responsible husband.

\section{There Is Only One Bull In This World}

Long, long ago, there was a famous Sukuma dance leader of magicians' group known as the Bagalu. His name was Gumha. He was not only a ningi [dance leader] but also a nfumu [practitioner of magic]. Gumba had a cock that used to spend the night on the roof of his house. Whenever wizards tried to cast their spells anywhere near Gumba's house at night the cock would crow alerting Gumba. 
Any attempt on Gumha's life always failed until he started boasting that no one could kill him.

A time came when Gumha became seriously sick and died. His followers were shocked, but appreciated that their leaders life had been taken by the Almighty God. They said, it is true that only one bull rules the world, that is God. It is he who has taken our heroes like Ibambangulu, Ng'wana, Malundi and Ngwana Ndele.

\section{The Man Who Tested His Wife's Love}

Once upon a time there were two men, who were very close friends. Once while discussing marriage one of them asked the other "My friend, do our wives love us truly?" The other responded "Yes, I have no doubt, my wife loves me very much".

"Is it true love?" he asked. His friend began having doubt and said, "I'll have to test her somehow".

One night, while they were sleeping, the man shook his wife awake and said he was dying. After a short while he feigned death. His wife, got out of bed, lit a fire and started preparing herself a meal, instead of weeping and mourning her loss. When the meal was ready she remembered some honey she had kept in a calabash, to the left of their bed. To reach the honey, she had to stand on her husbands 'body' because she was short. After the meal she cleared and cleaned the utensils, and her mouth. Only then did she start wailing loudly "My husband, my husband is dead, what shall I do?" The neighbours quickly assembled outside and she started sobbing, saying and pretending how much she loved him. While she was still at the farce, her husband walked out, stunning the gathering. He then explains to them what and why he had done what he did.

"Go home, friends" he told the neighbours "I now know that my wife does not truly love me".

This teaches us that even if somebody says they love you, it could be superficial. We should always leave room for doubt, benefit of doubt. 


\section{Desire Has No Rest}

A long long time ago, there was a young man, who's desire to become rich was a passion he could not ignore. The ambition burned in him till he devised a plan, to fulfil his dream.

One day he caught a grasshopper, and carried it with him to a far off village, where he arrived at dusk. He asked for a place to sleep. For the grasshopper, he asked his hosts if it could sleep on a beam in the paultry house which they agreed.

In the morning, he found the chicken had eaten his grasshopper. He cried and made such a fuss, that he was given a hen as compensation.

Next day he took off with his hen and walked till dusk, when he arrived at another village. He asked for a place to sleep. His hosts promptly provided a place for him and his chicken.

He saw some space in the goat pen and asked if his hen could sleep there. Next morning the poor bird was dead, having been trampled on by the goats. Again the young man wept and made such a fuss. He was given a young goat as compensat ion.

As soon as he received the goat, the young man left the village and moved on, he arrived at another village at dusk, where he asked for a place to sleep. His hosts promptly provided a place for him and his goat. The young goat was put in the cow pen, unfortunately there was a stampede in the morning, and the poor goat was trampled and died. As usual the young man made such a fuss, demanding a cow which he was given.

On his way home he had to go through a thick forest and idea sprang in his mind and he cut of the cows tail and buried it leaving a little bit sticking out. He hid the cow then went into the next village crying, aloud that his cow was being swallowed by the soil. The villagers rallied together and came to his aid. When they came to the site he showed them the little bit of tail sticking out and called out to them to save his cow. So they started pulling at the tail, but alas, the tail came out. The young man cried and made a fuss demanding compensation from the villagers, who then gave him a cow each as compensation. He returned to his village a rich man with many cows. 
These are some of the Sukuma narratives. One appreciates that they are quite varried in messages and rich in style.

\section{THE VALUE OF ORAL LITERATURE IN THE SUKUMA COMMUNITY}

Oral literature, whether recited, narrated, declaimed or sung has got specific purposes to serve in the society. Often, it is used to educate and entertain members of society.

People in traditional Sukuma society and even now taught about their culture and truth of life through different genres of oral literature according to the occasions. Oral literature helps them to grow up according to societal expectations.

Oral literature embodies history, cultural values, philosophy and beliefs of a people. Through this literature we learn a lot about societies. It is therefore safe to state that oral literature is an instrument of cultural education. This literature teaches what society likes and what it hates.

For example, it is taboo to kill among the Sukuma. It is also taboo to eat human meat. This woman in narrative, therefore, commits double "sin" in the community. The "sin" is made even more serious when one is made to understand that the people who are supposed to be killed and eaten are the grandchildren to this old woman. She appears to belong to the community of animals than to that of humans. In the story, we do to see her interacting with human beings except the grandchildren when she plans to kill and eat. In the story under discussion, it is significant that the grandchildren play a trick on their grandmother and the wild animals by putting logs of wood in their beds. When the animals fail to get their feast, they must turn their anger on something. The object against which the anger is turned is the old woman. By the woman being killed and eaten by animals, justice is being done. There is a kiswahili proverb, "Mchimba shimo huingia mwenyewe" (He who dig's a well/ hole/grave gets into himself). That if one plans evil, that evil will destroy the one who plans it. The story also stresses the Sukuma people's view of life. That the elderly have the responsibility to pro- 
tect the young people. Any actions against this will be betrayal of the individual and the entire Sukuma community.

Among the Sukuma, children of different ages and from different families come together during playtime. At such times, they sing, tell stories and engage in riddling activities. These activities entertain children besides making them creative. 